\title{
Tachinid (Diptera: Tachinidae) parasitoids of spotted ash looper (Abraxas pantaria) in Krka National Park in Croatia
}

\author{
MILAN PERNEK ${ }^{1}$ \\ IVAN LUKIĆ ${ }^{1}$ \\ NIKOLA LACKOVIĆ 1 \\ EJUP COTA ${ }^{2}$ \\ HANS-PETER TSCHORSNIG ${ }^{3}$ \\ ${ }^{1}$ Division for Forest Protection and Game Management \\ Croatian Forest Research Institute \\ Cvjetno naselje 41, 10450 Jastrebarsko, Croatia \\ ${ }^{2}$ Department of Plant Protection \\ Agricultural University of Tirana, \\ Koder-Kamez, 1029 Tirana, Albania \\ ${ }^{3}$ Staatliches Museum für Naturkunde \\ Rosenstein 1, 70191 Stuttgart, Germany

\section{Correspondence:} \\ Milan Pernek \\ e-mail:milanp@sumins.hr
}

Key words: Abraxas pantaria, Lepidoptera, Geometridae, Diptera, Tachinidae

Received July 1, 2015.

Revised December 10, 2015.

Accepted January 19, 2016.

\begin{abstract}
Background and purpose: Spotted ash looper, Abraxas pantaria (Lepidoptera: Geometridae) causes defoliations of narrow-leaved ash (Fraxinus angustifolia) in Croatia, mainly in Krka National Park. Since controlling pests with insecticides is not possible in protected areas, biological pest control might be a valuable option. The first step in the study of its application is the research on hosts and their natural enemies. Not much is known about the parasitoid spectrum of A. pantaria in Croatia, so the aim of this research is to identify the parasitoid species which could influence the population density of this potential forest pest.
\end{abstract}

Materials and methods: Pupae of A. pantaria were studied in 2010 at several locations along the River Krka in Krka National Park. This area was chosen because total defoliation of ash was observed in 2010.

Results and conclusions: Five tachinid species were reared from $\mathrm{Ab}-$ raxas pantaria: Phryxe nemea, Bactromyia aurulenta, Senometopia $s p$., Pales pavida and Eurysthaea scutellaris. All species are generalist parasitoids. Phryxe nemea is the first record for this host.

\section{INTRODUCTION}

Spotted ash looper (SAL), Abraxas pantaria (Linnaeus, 1767) (Lepi$\checkmark$ doptera: Geometridae) is a pest of ash (Fraxinus spp.) which temporarily causes high infestation in some parts of the Mediterranean region such as Portugal, Spain and Turkey (1-4). In Croatia, defoliations of narrow-leaved ash (Fraxinus angustifolia Vahl.) were recorded in Krka National Park, the last one in the period 2008-2010 and in 2014 (4). Such defoliation usually results in the loss of vitality and aesthetic value of the attacked ash trees. Additional negative effects are caterpillars hanging on silky threads and excrements falling from trees disturbing the visitors in the National Park.

Narrow-leaved ash is an important forest species in Croatia and it is also found as a horticultural species in parks and avenues $(1,4)$. The spotted ash looper has not yet been recorded in other Croatian regions (4), so it can be concluded that it has adapted to the Mediterranean area and that there is no threat for continental ash forests at present.

As control measures of pests using insecticides are not possible in protected areas in Croatia, the presence of natural enemies and their regulation ability is an important factor. Natural enemies (i. e. parasit- 
oids) as biological control agents are an important factor that influence the population density of forest pests (5). The first step in the study of the possibilities of using natural enemies for population control is to research the host/natural enemies' interactions (e.g. 5-7). Many studies of natural enemies of forest pests emphasize parasitoids as a significant factor in the decrease of the population (8).

Parasitoids of $S A L$ have been mentioned by several authors, e.g. Özbek and Çalmaşur (3), Pernek et al. (4), Baur (9). However, there is a lack of knowledge about the parasitoid spectrum of $S A L$ in Croatia where such a study has never been done before. A relatively high mortality rate of $S A L$ caused by the pathogenic fungi Beauveria bassiana has been recorded (4), and the presence of parasitoids has been observed, but not examined in detail (4).

The increased importance of $S A L$ as a potential forest pest of Fraxinus spp. in Croatia has prompted research on the biology of this species and on their natural enemy associates. The purpose of this paper is to present new records of parasitoid species belonging to tachinid flies (Diptera; Tachinidae) in the pupal stage of $S A L$, in order to build a base for further research of the possibilities for its control.

\section{MATERIALS AND METHODS}

Pupae of $S A L$ in the Krka National Park (KNP) were studied from 2009 to 2012 at several locations along the River Krka from Roški Slap (waterfall) (43⒌'32"N, $\left.15^{\circ} 58^{\prime} 45^{\prime \prime} \mathrm{E}\right)$ to the Monastery of St. Archangel

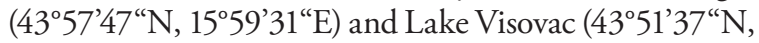
$\left.15^{\circ} 58^{\prime} 04^{\prime \prime} \mathrm{E}\right)$. This area was chosen because total defoliation of ash was observed in 2010.

The research of the biology of $S A L$ included field observations once a month in the period July-October during the years of research. During the pupal stage, the area under the damaged trees was searched and the upper soil layer on plots of $20 \times 20 \mathrm{~cm}$ was dug out and searched for pupae. In total, 10 plots were dug, from which the pupae were collected and used for the rearing and the identification of parasitoids. The depth of the soil where the pupae were found and collected was measured.

In September 2010, a total of 200 pupae of $S A L$ were collected and brought to the entomological laboratory of the Croatian Forest Research Institute for the analysis of parasitism. Each pupa was placed in a separate glass tube. The pupae were incubated under controlled temperature $\left(22{ }^{\circ} \mathrm{C}\right)$ with a relative humidity of $60 \%$ and a ratio of light: dark (L:D) 18:6.

The nomenclature and the arrangement of the tachinids follow the relevant catalogue of Herting \& DelyDraskovits 1993 (12). Summarized information on the biology and ecology of Central European species is provided by Tschorsnig \& Herting (10). Detailed informa- tion on the West Palaearctic hosts and the biology of the tachinid species can be found in Herting 1960 (11). This book is partly outdated, but the data on the biology remain valid, and the tachinid host lists have recently been corrected and updated by Tschorsnig (who also identified the tachinids of the present paper) to form a large catalogue for the Palaearctic region (in preparation). The specimens are kept in the Forest Research Institute.

\section{RESULTS}

Five tachinid species, all belonging to the Exoristinae subfamily, were reared from SAL in KNP, in 2010 and 2014:

Phryxe nemea (Meigen, 1824), 1 Oૈ, 1 †, 2014 [first record for this host].

Bactromyia aurulenta (Meigen, 1824), 1 †, 2014.

Senometopia sp., 1 †, 2014 [unidentifiable to species level].

Pales pavida (Meigen, 1824), 1 Ô, 21.IX.2010 [untypically small specimen, $4 \mathrm{~mm}$ body length].

Eurysthaea scutellaris (Robineau-Desvoidy, 1848), 1 Oे, 1 ㅇ, 21.IX.2010.

\section{DISCUSSION}

All the parasitoid species found during this research are generalist parasitoids (11) The five species reared can be characterized as below. The first three species lay eggs with a fully developed first larval stage directly on the hosts (= „ovolarviparous") whereas the last two lay very small (= "microtype") eggs on the host plants, and the eggs are swallowed by the host during feeding (11).

Phryxe nemea is a generalist parasitoid with many known lepidopterous hosts (115 host species are currently known after a recent count of Tschorsnig). $S A L$ is a first host record for this tachinid, but being a main parasitoid of Abraxas grossulariata (Linnaeus, 1758) this is not an unexpected result (more records are known from this geometrid host as, e. g., listed by Herting (11)). P. nemea is a first record for Croatia (Tschorsnig et al. (17)), while the species is common and widespread in Europe.

Bactromyia aurulenta is a generalist parasitoid species, with a slight preference on the families Geometridae and Yponomeutidae (11). There are several records from $A$. pantaria $(9,11,13-16)$. B. aurulenta is the first record for Croatia (10), while this species is not rare and is widespread in Europe.

For Senometopia sp., the specimen in question is a female of the Senometopia excisa group which consists of three species, S. excisa (Fallén, 1820), S. lena (Richter, 1980), and S. pilosa (Baranov, 1931). The female from KNP cannot be identified because male genitalia are nec- 
essary for identificaton to species level. Senometopia lena is known as a parasitoid from $S A L$ (9).

Pales pavida is misidentified on fig. 4 in Pernek et al. 2013 (4). The species is probably a female of Senometopia sp.

However, the tachinid material of Pernek et al. 2013 (4) is no more available, and it cannot be completely ruled out that also the true $P$. pavida was present among the eight specimens listed in table 5 of Pernek et al. 2013 (4).

Pales pavida is a common parasitoid species which has even more known hosts than Phryxe nemea (the current count (Tschorsnig, unpublished) is 230 host species). A few specimens have been recorded from $\operatorname{SAL}(3,9)$, but it is probably not a typical host. The dwarf-like specimen found during this research may indicate that the developmental conditions were not optimal and that SAL is not the optimal host.

Eurysthaea scutellaris is a tachinid that is preferably a parasitoid of families of „Microlepidoptera”, but several other lepidopterous families may be parasitized as well [11]. Several records exist for the host $S A L(9,11,14,18)$.

Apart from the species found during this research, the following five tachinids became known as parasitoids of SAL: Winthemia pruinosa Gil, 1931 (9, 14), Phryxe unicolor (Villeneuve, 1908) (9, 16), Nemoraea pellucida (Meigen, 1824) (11, 14), Panzeria [syn. Ernestia] argentifera (Meigen, 1824) (14), and Campylocheta inepta (Meigen, 1824) (14).

Acknowledgment: We gratefully acknowledge that this work has been partly supported by Croatian Science Foundation under the project 7616. This research was also partly financed by Krka National Park, Croatia within the project "Research of damage and spread of pathogenic fungi Phellinus pini on pine and research of bio-ecology and prognosis of population of spotted ash looper in Krka National Park". This work is dedicated to Anita Jurkovic, Krka National Park.

\section{REFERENCES}

1. PRIETO M 1986 Biology and morphology of Abraxas pantaria L. (Lepidoptera: Geometridae). Boln Sanid veg Plag 12 (2): 209-220

2. LIOVIĆ B, PERNEK M 2000 Abraxas pantaria L.- Štetnik na jasenu u NP Krka. Zbornik sažetaka priopćenja Sedmog hrvatskog biološkog kongresa 239: 305
3. ÖZBEK H, ÇALMAŞUR Ö 2010 Spotted ash looper, Abraxas pantaria (L.) (Lepidoptera: Geometridae), a new ash pest in Turkey. Turk J Zool 34: 351-358

4. PERNEK M, LACKOVIĆ N, MATOŠEVIĆ D 2013 Biology and natural enemies of spotted ash looper, Abraxas pantaria (Lepidoptera, Geometridae) in Krka National Park. Period biol 115: 371377

5. WEGENSTEINER R 1992 Untersuchungen zur Wirkung von Beauveria-Arten auf Ips typographus (Col., Scolytidae). Mitt dt Ges allg angew Ent 8: 104-106

6. PERNEK M, MATOŠEVIĆ D, HRAŠOVEC B, KUČINIĆ M, WEGENSTEINER R 2009 Occurrence of pathogens in outbreak populations of Pityokteines spp. (Coleoptera, Curculionidae, Scolytinae) in silver fir forests. J Pest Sci 82 (4): 343-349 http://dx.doi.org/10.1007/s10340-009-0259-8

7. HOLUŠA J, LUKÁŠOVÁ K, WEGENSTEINER R, GRODZKI W, PERNEK M, WEISER J 2013 Pathogens of the bark beetle I $p$ cembrae: microsporidia and gregarines also known from other Ips species. J appl Ent 137 (3): 181-187

8. BERRYMAN A 1986 Forest insects. Priciple and Practice of Population Management. Plenum Press, New York and London

9. BAUR H 2005 Determination List of Entomophagous Insects, Nr. 14. In: Identification Service of Entomophagous Insects. IOBC/ WPRS Bull 28 (11): 71 pp

10. TSCHORSNIG HP, HERTING B 1994 Die Raupenfliegen (Diptera: Tachinidae) Mitteleuropas: Bestimmungstabellen und Angaben zur Verbreitung und Ökologie der einzelnen Arten. Stuttg Beitr Naturk, Ser A (Biologie) 506: 170 pp

11. HERTING B 1960 Biologie der westpaläarktischen Raupenfliegen (Dipt., Tachinidae). Monogr angew Ent, Berlin (Parey) 16: 188 pp.

12. HERTING, B, DELY-DRASKOVITS, A 1993 Family Tachinidae. In: SOÓS, A \& PAPP, L (eds.): Catalogue of Palaearctic Diptera 13: 118-624. Budapest (Hungarian Natural History Museum)

13. PICARD F 1912 Notes biologiques sur quelques Coléoptères et Hyménoptères du Midi de la France. Bull Soc ent Fr 1912: 48-51

14. GIL J 1931 Notas sobre taquinidos españoles Dipt.). I. Algunas especies parásitas de orugas de El Escorial. Eos 7: 349-354

15. SILVA FA, NOGUEIRA CDS 1965 Notas sobre a entomofauna florestal portuguesa. - Archos Mus Bocage 1: 57-66

16. FORD TH, SHAW MR, ROBERTSON DM 2000 Further host records of some West Palaearctic Tachinidae (Diptera). Entomologist's Rec J Var 112: 25-36

17. TSCHORSNIG HP, RICHTER VA, CERRETTI P, ZEEGERS T, BERGSTRÖM C, VANHARA J, VAN DE WEYER G, BYSTROWSKI C, RAPER C, ZIEGLER J, HUBENOV Z 2004 Tachinidae. In: Fauna Europaea Service, http://www.faunaeur.org

18. SCHIRBER E. 1924 Sur Abraxas pantaria L. (Lép.) Revue Zool agric appl 23: 157-158

19. BLETON CA, FIEUZET L 1939 Notes sur quelques insectes auxiliaires observés dans la région de Fès. Bull Soc Sci nat Maroc 19: $57-65$ 